\title{
ВИКОРИСТАННЯ ҐРІД ДЛЯ ЗОВНІШНЬОГО ЗБЕРІГАННЯ МЕДИЧНИХ ЗОБРАЖЕНЬ В МЕДИЧНІЙ ІНФОРМАЦІЙНІЙ СИСТЕМІ
}

\author{
О. В. Дьомін, О. О. Харюк, А. В. Чергінець ${ }^{1}$ \\ ${ }^{1}$ /нститут сцинтиляційних матеріалів НАН України \\ Харківський національний університет імені В. H. Каразіна
}

\section{USING OF GRID AS EXTERNAL STORAGE FOR IMAGES IN MEDICAL INFORMATION SYSTEM}

\author{
O. V. Diomin, O. O. Kharyuk, A. V. Cherhinets ${ }^{1}$ \\ ${ }^{1}$ Institute for Scintillation Materials of NAS of Ukraine \\ V. N. Karazin Kharkiv National University
}

Вступ. У світі розвиваються та швидко поширюються технології, що пов'язані з Грід обчисленнями. Одним із актуальних напрямів цієї діяльності є використання Грід-технологій у медицині, зокрема створення великих баз для збереження медичних зображень.

32010 року в Україні здійснюється Національна науково-технічна програма впровадження та використання Грід-технологій. Найбільше застосування Грід-технології знайшли в галузі фізики високих енергій. Проте у рамках Програми підтримуються Грід-проекти й для інших галузей знань, у тому числі медицини. Одним із таких став проект «Створення системи зберігання медичних зображень 3 використанням Грід-технологій».

Результати та їх обговорення. Створено розподілену базу даних і сховище зображень на основі віртуальної організації (ВО) MedGrid. Відомо, що до складу системи входять: Парсер формату DICOM, сховище даних для зберігання файлів, сервер бази даних, модуль авторизації, модуль деперсоналізації пацієнта, API функції для доступу до системи зберігання, Веб-інтерфейс лікаря, інтерфейс адміністратора.

Кожен лікар отримує сертифікат, що дозволяє працювати 3 системою, завантажувати та переглядати дослідження. Лікар має доступ тільки до досліджень, що він завантажив, або до тих, посилання на які йому повідомляє інший користувач системи або пацієнт. Лікар може працювати з базою даних за допомогою звичайного Інтернет браузера, однак зручніше використовувати спеціалізовані клієнти доступу.

Для використання Грід-системи для зовнішнього зберігання медичних зображень у медичній інформаційній системі (МIC) створено спеціальне проміжне програмне забезпечення (ППО). 3 одного боку, ППО має стандартний інтерфейс DICOM-сервера, 3 іншого - інтерфейс доступу до Грід-системи за допомогою API функцій. ППО інтегрується до МIC як DICOM-сервер у локальній мережі закладу охорони здоров'я та може приймати зображення за мережевим DICOM стандартом. Після отримання медичного зображення ППО вилучає 3 нього персональні дані та розміщує їх у локальній базі даних. Після цього деперсоніфіковані зображення передаються на зберігання в Грід-систему. При запиті цих даних із локальної MIC зображення передається 3 Грід-системи. Потім до зображення додаються персональні дані, що збережені локально. Таким чином відновлюється початковий DICOM-файл.

Висновок. Спеціалізоване ППО дозволяє зберігати медичні зображення у Грід у деперсоніфікованому вигляді та організовувати доступ із MIC у прозорій для лікарів формі стандартного DICOM-сервера. 